\title{
PENGARUH METODE PEMBELAJARAN DAN KREATIVITAS TERHADAP KEMATANGAN SEKOLAH SISWA TAMAN KANAK-KANAK MANDIRI PLUS LUBUK PAKAM
}

\author{
Rahmaini Raya Lubis ${ }^{1}$, Abdul Hasan Saragih ${ }^{2}$ \\ Pascasarjana Universitas Negeri Medan ${ }^{1,2}$ \\ rahmaini_raya@yahoo.com ${ }^{l}$
}

\begin{abstract}
Abstrak: Tujuan penelitian ini adalah: (1) mengetahui kematangan antara anak taman kanakkanak yang diajar menggunakan metode bermain sambil belajar dengan metode formal; (2) mengetahui kematangan antara anak taman kanak-kanak yang memiliki kemampuan kreativitas tinggi dan kreativitas rendah; dan (3) mengetahui interaksi antara metode pembelajaran dan kreativitas terhadap kematangan sekolah pada anak taman kanak-kanak. Hasil penelitian ini menunjukkan bahwa: (1) terdapat perbedaan rata-rata hasil tes kematangan sekolah anak yang diajar dengan metode pembelajaran bermain secara keseluruhan baik pada kelompok anak dengan kreativitas tinggi maupun kreativitas rendah lebih tinggi dibandingkan dengan rata-rata hasil tes kematangan sekolah anak yang diajar dengan metode pembelajaran formal. (2) hasil tes kematangan sekolah anak dengan kreativitas tinggi secara keseluruhan baik yang diajar dengan strategi pembelajaran bermain maupun metode pembelajaran formal lebih tinggi dibandingkan dengan rata-rata hasil tes kematangan sekolah anak dengan kreativitas rendah; dan (3) terdapat interaksi antara metode pembelajaran dengan kreativitas.
\end{abstract}

Kata Kunci: metode pembelajaran, kreativitas, kematangan sekolah siswa taman kanak-kanak

Abstract: The purpose of this study were: (1) the maturity of the child kindergarten is taught using the method of play while learning with formal methods; (2) the maturity of the child kindergarten which has the ability of high creativity and low creativity; and (3) the interaction between teaching methods and creativity of school maturity of children of kindergarten. The results showed that: (1) there are differences in average test results maturation school children learn by learning to play the overall good of the group of children with high creativity and creativity prices higher than the average of test results maturation school children taught by formal learning methods. (2) the results of tests of school maturity of children with high overall creativity both taught by learning strategies and teaching methods play a formal higher than the average child's school maturity test results with low creativity; and (3) there is interaction between learning and creativity.

Keywords: learning, creativity, maturity school kindergarten students

\section{PENDAHULUAN}

Anak usia 4-6 yang sekolah di taman kanak-kanak merupakan anak dengan rentang usia dini. Pada usia tersebut seluruh aspek perkembangan kecerdasan Intelegensia Question (IQ), Emotional Question (EQ), dan Spiritual Question (SQ) tumbuh dan berkembang luar biasa. Pada umumnya tingkat perkembangan anak usia dini tersebut masih melihat segala sesuatu sebagai satu keutuhan (holistik) dan hanya mampu memahami konsep secara sederhana. Proses pembelajaran masih bergantung kepada objek-objek konkrit dan pengalaman yang dialami secara langsung.

Perhatian terhadap pendidikan anak usia dini agar kecerdasan, kepribadian dan prilaku sosial anak dapat berkembang secara optimal. Usia dini merupakan usia di mana anak akan sangat mudah menerima rangsangan dari lingkungannya. Perlakuan yang tepat dari lingkungannya diharapkan akan membawa perubahan positif bagi perkembangannya. Hal ini dapat dilakukan sebagaimana dijelaskan Hurlock dalam Moeslichatoen (2004:8) sebagai berikut: (1) mendorong anak bertingkah laku sesuai dengan yang diharapkan dan menghilangkan tingkah laku yang tidak diharapkan, (2) tingkah laku yang diharapkan apabila dilakukan anak akan memberikan konsekuensi yang menyenangkan, sedangkan tingkah laku yang tidak diharapkan akan menumbuhkan penyesalan pada diri anak, (3) 
tingkah laku yang diharapkan apabila dibina secara terus menerus pada saatnya akan terjadi dengan sendirinya, atas prakarsa anak sendiri meskipun tidak ada pengawasan dari guru, dan (4) anak perlu mendapat kesempatan untuk mengubah tingkah laku yang tidak diharapkan itu. Bertitik tolak dari hal di atas, maka pendidikan dalam kerangka pembentukan perkembangan jasmani dan rohani anak harus mensinergiskan aspek-aspek tumbuh kembang anak.

Aspek tumbuh kembang anak yang harus dikembangkan sebagaimana dijelaskan Pratisti (2008:1) mencakup tiga aspek yaitu: (1) aspek fisik, (2) aspek mental psikologis, dan (3) aspek sosial. Aspek fisik dapat dilihat melalui pertumbuhan tulang, otot-otot, sistem syaraf serta organ tubuh. Aspek mental psikologis mencakup pertumbuhan mental yang berkesinambungan yang dapat dilihat melalui peningkatan kemampuan untuk memecahkan masalah serta kemampuan untuk menghasilkan ide-ide. Sedangkan aspek sosial adalah kemampuan anak untuk mampu beradaptasi dengan lingkungan, atau menyesuaikan diri dengan kebutuhan serta tuntutan dari lingkungan sosial disekitarnya.

Pendidikan anak usia dini memegang peranan yang penting dan menentukan bagi sejarah perkembangan anak selanjutnya, sebab pendidikan anak usia dini merupakan fondasi bagi dasar kepribadian anak. Perlakuan pendidikan yang tepat dari lingkungannya akan membawa dampak bagi perkembangan anak, baik secara fisik, kognitif, sosial maupun emosi. Begitu pula sebaliknya, perlakuan yang kurang tepat akan membawa kerugian bagi perkembangan mereka. Riyanto dan Handoko (2004:20) menjelaskan pentingnya setiap orang tua dan pendidikan memahami kemampuankemampuan yang perlu dicapai anak dalam masa awal pendidikan yaitu: (1) belajar keterampilan fisik yang perlu untuk bermain, bergerak semi rutin dan rutin, (2) membangun sikap yang sehat terhadap diri sendiri, (3) belajar menyesuaikan diri dengan teman-teman sebaya, (4) mengembangkan sikap terhadap kelompok sosial dan keluarga, (5) mengembangkan pengertian-pengertian yang diperlukan dalam kehidupan sehari-hari, (6) mengembangkan hati nurani, penghayatan moral dan tata nilai, (7) mengembangkan keterampilan dasar untuk menulis, membaca dan berhitung, dan (8) mengembangkan diri untuk mencapai kebebasan pribadi.
Pendidikan anak usia dini telah dimulai sejak abad ke 17 oleh Yohan Armos Commenius. Commenius memandang anak didik sesuai dengan sifatnya yang khas dan berbeda dengan orang dewasa. Perhatiannya tentang pendidikan anak usia dini khususnya anak usia taman kanak-kanak terus berkembang sampai abad berikutnya, hal ini terbukti dengan berdirinya taman kanak-kanak pertama yang digagas oleh Friederich Wilhem Froebel pada tahun 1782. Dalam melaksanakan proses pendidikannya menggunakan metode belajar bermain, dalam hal ini, Mutiah (2010:91) menjelaskan bahwa bermain adalah kegiatan yang penting bagi pertumbuhan dan perkembangan anak.

Rachmawati dan Kurniati (2010:1) menjelaskan tujuan pendidikan taman kanakkanak adalah untuk membantu meletakkan dasar ke arah perkembangan sikap, pengetahuan, keterampilan dan daya cipta yang diperlukan anak dalam menyesuaikan diri dengan lingkungannya dan untuk pertumbuhan dan perkembangan selanjutnya. Dengan demikian orientasi belajar anak hanya ditekankan pada pencapaian prestasi akademik mungkin anak dapat mencapai kemampuan sesuai dengan harapan guru, namun hal ini dapat menimbulkan dampak negatif bagi perkembangan anak selanjutnya.

Buhler dan Hetzer, dalam Munandar (1999:5) berpendapat yang dimaksud dengan kematangan sekolah adalah sejauhmana anak telah cukup matang dari segi fisik untuk dapat memasuki sekolah. Pendapatnya ini berhubungan dengan penelitian yang dilakukannya yang membuktikan bahwa adanya korelasi signifikan antara perkembangan fisik dengan kematangan jiwa anak, sehingga tingkat perkembangan fisik anak sekolah dapat merupakan patokan bagi kematangan jiwa anak. Rasmin (2000:12) menjelaskan kematangan sekolah merupakan suatu kondisi anak yang telah memiliki kesiapan yang cukup memadai baik secara fisik maupun mental, untuk memenuhi tuntutan dalam lingkungan pendidikan formal, dalam hal ini meliputi aspek penguasaan materi pelajaran dan kemampuan membina interaksi antara teman, guru dan murid. Selanjutnya

Kriteria kematangan dijelaskan Rasmin (2000:49) yaitu apabila anak usia taman kanakkanak telah dapat mengendalikan fungsi tubuhnya, telah mandiri dan mengenal rasa tanggung jawab, sudah mengenal aturan 
pergaulan sehari-hari, terampil dalam menggunakan alat tulis, serta anak telah mengenal angka dan huruf. Anak yang matang untuk belajar yaitu anak telah memiliki minat untuk belajar, anak telah memiliki perkembangan sosial yang memadai, memiliki kondisi jasmani yang sehat untuk melakukan tugas-tugas di sekolah, sehingga untuk untuk memasuki suatu lembaga pendidikan sekolah dasar anak harus memiliki kemampuan antara lain, anak harus sudah berkembang dalam kecakapan pengamatannya artinya anak telah mampu mengamati sesuatu secara teliti, selanjutnya anak tersebut harus sudah dapat menguasai bahasa secara aktif dan pasif. Dengan bahasa aktif berarti ia sudah memiliki kemampuan untuk berbicara dan secara pasif berarti sudah dapat memahami bahasa yang diucapkan oleh orang lain. Selain itu, anak tersebut harus sudah memiliki kecakapan yang bersifat psikomotoris seperti gerakan tangan dan jari untuk belajar menulis.

Seels dan Richey (1994:140) menjelaskan metode pembelajaran adalah spesifikasi pemilihan dan pengurutan kegiatan dalam suatu pengajaran pelajaran tertentu. Selanjutnya Sells dan Richey (1994) menjelaskan bahwa berkaitan dengan konteks teknologi pemebalajaran, maka penelitian yang berkaitan dengan metode pengajaran berada pada kawasan desain yang meliputi desain sistem pembelajaran, desain pesan, strategi pembelajaran dan karakteristik pebelajar.

Hamalik (1993:4) berpendapat bahwa metode pembelajaran sebagai suatu cara, teknik atau langkah-langkah yang akan ditempuh dalam proses belajar mengajar. Sedangkan Sudjana (2001:14) menjelaskan metode pembelajaran adalah setiap kegiatan yang ditetapkan pendidik untuk mencapai tujuan belajar.

Moeslichatoen (2004:9) menjelaskan metode merupakan cara yang dalam fungsinya merupakan alat untuk mencapai tujuan kegiatan. Penggunaan metode pembelajaran akan membawa perbedaan yang berarti pada proses belajar anak. Metode adalah cara yang sebaik-baiknya yang digunakan untuk mencapai suatu tujuan. Pendapatnya yang lain menyatakan bahwa metode adalah suatu prosedur untuk mencapai suatu objek. Dengan demikian maka metode adalah cara yang sistematik dan baik dengan prosedur dan proses tertentu untuk mencapai tujuan yang diinginkan.
Masa kanak-kanak adalah masa yang penting untuk sepanjang usia hidupnya, karena masa ini merupakan masa keemasan dan juga masa peka untuk belajar. Pada masa ini fondasi kecerdasan, kepribadian, moral dan sikap anak mulai di bentuk. Oleh sebab itu agar anak usia taman kanak-kanak menjadi generasi yang berkembang optimal, guru sebaiknya mampu secara bijak memilih strategi dan metode pembelajaran yang sesuai yaitu metode bermain. Musfiroh (2008:1) menjelaskan bermain adalah kegiatan yang dilakukan atas dasar kesenangan dan tanpa mempertimbangkan hasil akhir. Kegiatan tersebut dilakukan secara sukarela tanpa paksaan atau tekanan dari pihak luar.

$$
\text { Selanjutnya Musfiroh }
$$
menjelaskan bermain mengandung unsur: (1) menyenangkan dan mengembirakan, (2) dorongan bermain muncul dari anak bukan paksaan orang lain, (3) anak melakukan spontan dan sukarela, (4) anak ikut serta secara bersama-sama sesuai peran masing-masing, (5) anak berlaku pura-pura, atau memerannkan sesuatu, anak pura-pura marah atau pura-pura menangis, (6) anak menetapkan aturan main sendiri, baik aturan yang diadopsi dari orang lain maupun aturan yang barus, (7) anak berlaku aktif, (8) anak bebas memilih mau bermain apa dan beralih kegiatan bermain lain, bermain bersifat fleksibel.

Rahman (2005:27) berpendapat ada beberapa prinsip metode pembelajaran yang dapat diterapkan pada anak usia dini berkaitan dengan aktivitas bermain sambil belajar yaitu: (1) berpusat pada anak, (2) partisipasi aktif, (3) bersifat holistik dan integratif, (4) fleksibel, dan (5) perbedaan individual

Untuk dapat lebih memahami tentang metode bermain maka yang harus diketahui adalah tentang pengertian bermain. Dworetzky dalam Moeslichatoen (2004:31) memberikan batasan tentang arti bermain dengan memisahkan aspek tingkah laku yang berbeda dalam bermain. Terdapat lima kriteria dalam bermain: (1) motivasi intrinsik, tingkah laku bermain pada anak di motivasi dari dalam diri, karena itu dilakukan demi kegiatan itu sendiri dan bukan karena adanya tuntutan dari masyarakat, (2) pengaruh positif, tingkah laku itu menyenangkan untuk dilakukan, (3) bukan kegiatan yang dilakukan sambil lalu, tingkah laku itu bukan dilakukan sambil lalu karena tidak mengikuti pola atau urutan yang sebenarnya, melainkan lebih bersifat pura-pura, 
(4) cara/tujuan, cara bermain lebih diutamakan dari pada tujuannya. Anak lebih tertarik pada tingkah laku itu sendiri dari pada keluaran yang dihasilkan, dan (5) kelenturan, bermain itu merupakan perilaku yang lentur. Kelenturan itu ditunjukkan baik dalam bentuk maupun dalam hubungannya serta berlaku dalam setiap situasi.

Bermain merupakan ciri aktivitas anak taman kanak-kanak yang khas. Pada kurun usia ini dinamakan juga sebagai periode keemasan (golden age) dalam proses perkembangan seorang anak, yang pada akhirnya anak akan mengalami lompatan kemajuan secara fisik, sosial dan emosional. Kegiatan bermain merupakan latihan untuk mengkonsolidasikan berbagai pengetahuan dan keterampilan kognitif yang baru dikuasai sehingga dapat berfungsi secara efektif. Tedjasaputra (2003:20) menjelaskan melalui bermain anak diharapkan berkembang pribadinya, sosial dan emosional, melalui bermain amak merasakan pengalaman, emosi, sedih, senang, bergairah, kecewa, bangga dan marah, serta memahami kaitan dirinya dan lingkungannya. Jadi bermain merupakan cermin perkembangan anak.

Moeslichatoen (2004:32) memberi uraian tentang bermain yaitu anak dapat melakukan aktivitas yang positif dalam memenuhi kebutuhan perkembangan dimensi fisik, motorik, kognitif, kreativitas, bahasa, emosi, sosial, nilai dan sikap hidup. Dari pengertian di atas selanjutnya beliau menguraikan sebagai berikut: (1) melalui bermain dapat melakukan koordinasi otot kasar, bermacam cara dan teknik dapat dipergunakan dalam kegiatan ini seperti berjalan, berlari, meloncat, melempar, menendang dan sebagainya, (2) melalui kegiatan bermain anak dapat melatih menggunakan kemampuan kognitifnya untuk memecahkan berbagai masalah seperti kegitan mengukur isi, mengukur berat, membandingkan, mencari jawaban yang berbeda dan sebagainya, (3) melalui kegitan bermain anak dapat mengembangkan kreativitasnya yaitu melakukan kegiatan yang mengandung kelenturan, memanfaatkan imajinasi atau ekspresi diri. Kegiatan ini dapat berupa pemecahan masalah, mencari cara baru dan sebagainya, (4) melalui kegiatan bermain anak juga dapat melatih kemampuan bahasanya dengan cara mendengarkan beraneka bunyi, mengucapkan suku kata atau kata, memperluas kosa kata, berbicara dengan bahasa Indonesia yang baik dan benar, (5) melalui bermain anak dapat meningkatkan kepekaan emosinya dengan cara mengenalkan bermacam-macam perasaan, mengenalkan perubahan perasaan, membuat pertimbangan dan menumbuhkan percaya diri, dan (6) melalui bermain anak dapat mengembangkan kemampuan sosialnya, seperti membina hubungan dengan anak lain, bertingkah laku sesuai dengan tuntutan masyarakat, menyesuaikan diri dengan teman sebaya, dapat memahami tingkah lakunya sendiri dan faham bahwa setiap perbuatan ada konsekuensinya.

Selanjutnya Moeslichatoen (2004:63) menjelaskan langkah-langkah kegiatan bermain melalui urutan: (1) kegiatan pra bermain, (2) kegiatan bermain, dan (3) kegiatan penutup. Kegiatan pra bermain merupakan kegiatan penyiapan anak dalam melaksanakan kegiatan bermain. Kegiatan pra bermain yaitu: (1) kegiatan penyiapan siswa dalam melaksanakan kegiatan bermain meliputi: (a) guru mengkomunikasi kepada anak tujuan kegiatan bermain, (b) guru mengkomunikasikan batasanbatasan yang harus dipatuhi anak, (c) guru menawarkan peran kepada masing-masing anak untuk disepakati, dan (d) guru memperjelas peran apa yang harus dilakukan, dan (2) kegiatan penyiapan bahan dan peralatan yang diperlukan dalam bermain. Kegiatan bermain dilakukan dengan langkah-langkah: (1) anak bermaian sesuai dengan peran yang telah ditentukan sebelumnya, dan (2) ketika proses bermain berlangsung guru memberi bimbingan. Kegiatan penutup dilakukan guru dengan: (1) menarik perhatian dan membangkitkan minat anak tentang aspek-aspek yang terdapat dalam kegiatan bermain, dan (2) menghubungkan pengalaman anak dengan situasi di rumah atau di tempat umum lainnya.

Berkaitan dengan jenis permainan dijelaskan Musfiroh (2008) meliputi: (1) permainan kecerdasan bahasa antara lain: gambar buah, huruf yang sama, bertukar nama, tebak kata, benda apa namanya, (2) permainan kecerdasan logika-matematik antara lain: tata balok, tata angka, hitung benda, hitung langkah, panjang mana, besar mana, cari yang sama, timbang ukur, (3) permainan kecerdasab visual spasial antara lain: merah mana, apa warnanya, menara, kanan-kiri, hiplak koin, gambar pagar, (4) permainan kecerdasan kinesteteik antara lain: jalan rupa-rupa, jalan mangkuk, patung dirijen, meronce manik-manik, mengambil dengan penjepit, jahit jelujur, (5) permainan kecerdasan musikal antara lain: doremi, 
mengejar lagu, suara apa itu, suara siapa itu, lagu selang-seling, (6) permainan kecerdasan intrapersonal antara lain siapa aku, yang kusuka yang dia suka, suara sedih suara senang, jadi apa, (7) permainan kecerdasan naturalis meliputi: telur ayam, mana buahku, daun kering daun segar, buah apa namanya, apa makanannya, dan (8) kecerdasan eksistensial antara lainL jika tanpa, kita menjadi titik, banyak maunya, hujan atau panas.

Semiawan (2002) menjelaskan pembelajaran secara formal (banyak hafalmenghafal) pada umur muda, mengakibatkan belahan otak kiri yang berfungi linier, logis dan teratur menjadi lebih dipentingkan, sehingga belahan otak kanan yang berfungsi dalam mengembangkan imajinasi dan kreativitas jadi terabaikan. Kegiatan mengajarkan membaca, menulis dan berhitung pada anak taman kanakkanak berarti mengkonsentrasikan waktu anak hanya pada satu bidang tertentu yang sangat terbatas sifatnya, sedangkan mereka lebih memerlukan waktunya untuk memperoleh kesempatan yang luas dalam mengenal dunianya dan mengembangkan kepribadiannya.

Selanjutnya Hartono (2002:19) mengatakan dalam metode pembelajaran secara formal di taman kanak-kanak, proses pembelajaran yang berlangsung tidak ubahnya seperti pendidikan di sekolah dasar. Segala program kegiatan dilakukan dengan tertib, memiliki aturan-aturan yang ketat dan suasananya bersifat formal.

Hergenhahn dan Olson (2008:490) mendefinisikan kreativitas adalah inovasi yang berasal dari sintesis pengaruh dari beberapa model atau dari mengamati suatu model menunjukkan strategi pemecahan masalah yang tidak lazim. Sternberg (2008:398) menjelaskan kreativitas sebagai proses memproduksi sesuatu yang orisinil dan bernilai. Sesuatu di sini bisa memiliki banyak bentuk, bisa berupa sebuah teori, sebuah tarian, sebuah zat kimia, sebuah proses atau prosedur, sebuah cerita, sebuah simponi ataupun yang lain. Selanjutnya Rachmawati dan Kurniati (2010:14) menjelaskan kreativitas merupakan suatu proses mental individu yang melahirkan gagasan, proses, metode ataupun produk baru yang efektif yang bersifat imajinatif, estetis, fleksibel, integrasi, suksesi, diskontinuitas yang berdaya guna dalam berbagai bidang untuk pemecahan suatu masalah.

Santrock (2008:366) menjelaskan kreativitas adalah kemampuan berpikir tentang sesuatu dengan cara baru dan tak biasa dan menghasilkan solusi yang unik atas suatu problem. Selanjutnya Santrock menjelaskan untuk menumbuhkembangkan kreativitas pada anak maka beberapa hal yang dapat dilakukan adalah: (1) kreativitas, (3) jangan terlalu mengatur anak, (4) mendorong motivasi internal, (5) mendorong pemikiran fleksibel dan main, dan (6) mengenalkan anak dengan orangorang kreatif.

Woolfolk (2009:90) mendefinisikan kreativitas adalah kemampuan untuk menghasilkan karya yang orisinal, tetapi tepatguna dan bermanfaat. Selanjutnya Woolfolk menjelaskan sumber kreativitas ada tiga yaitu: (1) keterampilan relevan-ranah termasuk berbagai talenta dan kompetensi yang bermanfaat untuk bekerja di ranah itu, (2) proses-proses relevan-kreativitas termasuk berbagai kebiasaan kerja dan ciri kepribadian, dan (3) motivasi tugas intrinsik atau keingintahuan atau keterpersonaan yang mendalam terhadap tugas. Selanjutnya Woolfolk (2009:97) menjelaskan perlakuan guru di kelas yang dapat mendorong kreativitas siswa dengan cara menerima jawaban-jawaban yang tidak biasa dan imajinatif, memberi model pemikiran divergen, menggunakan brainstorming (curah pendapat) dan menoleransi perbedaan pendapat.

Rose (2003:176) menjelaskan kreativitas selalu melibatkan banyak kerja keras dan persiapan, oleh karena itu memperoleh pengetahuan dan latar belakang yang terperinci mengenai suatu topik adalah kunci kreativitas. Selanjutnya Rose menjelaskan tahapan dalam kreativitas yaitu: (1) pemahaman, (2) kombinasi, dan (3) bandingkan yang baru dengan yang lama. Pemahaman berkaitan dengan mendefinsikan masalah secara cermat, lalu menyaring data yang relevan dari yang tidak relevan dan menentukan petunjuk yang penting. Kombinasi berkaitan dengan bagaimana mengombinasi ulang ide dalam cara baru dengan cara menggabungkan ide lama menjadi konsep baru. Bandingkan yang baru dengan yang lama berkaitan dengan menilai ide baru setelah membandingkannya dengan yang lama.

Rose (2003:178) menjelaskan kerangka kerja kreativitas yaitu: (1) sibukkan diri dengan mengumpulkan informasi sebanyak-banyaknya, (2) berpikir dari berbagai sudut pandang, (3) hasilkan alternatif ide sebanyak-banyaknya, (4) carilah kombinasi terbaik dari semua ide 
tersebut, (5) tetapkanlah kombinasi terbaik, dan (6) terapkan.

De Porter dan Hernacki (2003:292) mengilustrasikan kreativitas sebagai berikut: luangkan waktu sesaat untuk mengingat beberapa situasi di mana anak berhasil mencapai tujuan ketika situasinya tampak tidak memungkinkan. Anak terjatuh atau terperangkap, atau tertangkap daam suatu lingkaran yang tak pernah anda masuki sebelumnya tetapi anak dapat menemukan jalannya.

Selanjutnya De Porter dan Hernacki (2003:301) menjelaskan proses kreativitas mengalir melalui lima tahapan yaitu: (1) persiapan, (2) inkubasi, (3) iluminasi, (4) verifikasi, dan (5) aplikasi. Persiapan berkaitan dengan mendefinisikan masalah, tujuan atau tantangan. Inkubasi berkaitan dengan mencerna fakta-fakta dan mengolahnya dalam pikiran. Iluminasi berkaitan dengan mendesak kepermukaan, gagasan-gagasan bermunculan. Verifikasi berkaitan dengan memastikan apakah solusi itu benar-benar memecahkan masalah. Aplikasi berkaitan dengan mengambil langkahlangkah untuk menindaklanjuti solusi.

$$
\text { Selanjutnya Hawadi (2004:28) }
$$

menjelaskan lima faktor yang dapat dilihat sebagai variasi dalam kreativitas yaitu: (1) faktor jenis kelamin, (2) status sosial ekonomi, (3) urutan kelahiran, (4) urutan keluarga, dan (5) lingkungan perkotaan dan pedesaan.

Dalam PP RI nomor 27 tahun 1990 tentang pendidikan taman kanak-kanak dinyatakan bahwa taman kanak-kanak adalah salah satu pendidikan dini bagi anak usia 4 tahun sampai memasuki pendidikan dasar (Patmonodewo, 2003:59). Moeslichatoen (2004:3) menjelaskan kegiatan pembelajaran di taman kanak-kanak adalah untuk membantu meletakkan dasar ke arah perkembangan sikap, pengetahuan, keterampilan dan daya cipta yang diperlukan oleh anak dalam menyesuaikan diri dengan lingkungannya dan untuk pertumbuhan serta perkembangan selanjutnya.

Froebel dalam Patmonodewo (2003:6) menjelaskan bahwa taman kanak-kanak adalah taman bermain sambil belajar, tempat di mana anak belajar menyesuaikan diri dengan beberapa hal sebelum anak memasuki sekolah ke jenjang yang lebih tinggi. Di taman kanakkanak inilah anak mulai belajar bersosialisasi, mandiri dan mulai patuh pada otoritas selain orang tua. Selanjutnya menjelaskan bahwa taman kanak-kanak adalah tempat bermain, bernyanyi mengerjakan pekerjaan tangan bersama-sama serta tempat anak untuk melatih daya cipta dengan menggunakan alat-alat permainan.

Snowmen dalam Patmonodewo (2003:32) menjabarkan ciri-ciri anak taman kanak-kanak yang meliputi aspek fisik, sosial, emosi dan kognitif anak. Ciri-ciri tersebut dapat dijabarkan kepada ciri fisik, ciri sosial, ciri emosional dan ciri kognitif. Ciri fisik, anakanak taman kanak-kanak telah memiliki pengusaan (kontrol) terhadap tubuhnya dan sangat menguasai kegiatan yang dilakukan sendiri. Kegiatan seperti berlari, melompat, memanjat, dan lain-lain. Biasanya merupakan kegiatan yang sering dilakukan oleh anak. Selain itu, otot-otot besar pada anak taman kanak-kanak lebih berkembang dari kontrol terhadap jari dan tangan, sehingga pada masa ini anak belum terampil dalam melakukan kegiatan-kegiatan yang menuntut kemampuan motorik halus dan rumit. Anak taman kanakkanak pada umumnya masih kesulitan dalam memusatkan pandangannya pada objek yang kecil ukurannya. Hal ini yang menyebabkan anak sulit mengembangkan kemampuan koordinasi visual motorik.

Berdasarkan kajian teoritis, maka hipotesis yang diajukan dalam penelitian ini adalah: (1) Kematangan sekolah pada anak taman kanak-kanak yang diajar dengan metode bermain sambil belajar lebih tinggi dibandingkan dengan anak taman kanak-kanak yang di ajar dengan metode pembelajaran secara formal; (2) Kematangan sekolah pada anak taman kanak-kanak yang memiliki kemampuan kreativitas tinggi lebih tinggi dari pada anak taman kanak-kanak yang memiliki kemampuan kreativitas rendah; dan (3) Terdapat interaksi antara metode pembelajaran dan kreativitas dalam memberikan pengaruh terhadap kematangan sekolah.

\section{METODE}

Penelitian ini dilakukan di taman kanak-kanak Mandiri Plus Lubuk Pakam. Populasi yang digunakan dalam penelitian ini adalah seluruh siswa taman kanak- kanak Mandiri Plus Lubuk Pakam dalam tingkatan B yang terdiri dari 4 kelas.

Teknik penentuan sampel digunakan cluster random sampling. Teknik ini dipilih karena yang disampling dari populasi adalah jumlah kelas (sebanyak 4 kelas) bukan jumlah siswa dalam populasi. Sampel yang diambil 
terdiri dari dua kelompok yaitu, dua kelas dilakukan pembelajaran metode bermain dan dua kelas lainnya dilakukan pembelajaran formal. Kemudian berdasarkan karakteristik kreativitas, kelas dibedakan antara kelompok siswa dengan kreativitas tinggi dan kelompok siswa dengan kreativitas rendah.

Dalam penelitian ini metode yang digunakan adalah metode quasi eksperimen.
Metode ini dipilih untuk mengetahui metode pembelajaran terhadap kematangan sekolah, dengan memberikan 2 jenis perlakuan yang berbeda. Desain yang digunakan dalam penelitian ini adalah desain faktorial $2 \times 2$. Desain tersebut dapat digambarkan sebagai berikut ini:

Tabel 1 Desain Penelitian

\begin{tabular}{|c|c|c|}
\hline \multirow{2}{*}{ Kreativitas $(\mathrm{B})$} & \multicolumn{2}{|c|}{ Metode Pembelajaran $(\mathrm{A})$} \\
\cline { 2 - 3 } & Kelas B $^{1}$ & Kelas B $^{2}$ \\
\cline { 2 - 3 } & Bermain $\left(\mathrm{A}_{1}\right)$ & Formal $\left(\mathrm{A}_{2}\right)$ \\
\hline Tinggi $\left(\mathrm{B}_{1}\right)$ & $\mathrm{A}_{1} \mathrm{~B}_{1}$ & $\mathrm{~A}_{2} \mathrm{~B}_{1}$ \\
\hline Rendah $\left(\mathrm{B}_{2}\right)$ & $\mathrm{A}_{1} \mathrm{~B}_{2}$ & $\mathrm{~A}_{2} \mathrm{~B}_{2}$ \\
\hline
\end{tabular}

Keterangan:

A : Metode Pembelajaran

B : Kreativitas

$\mathrm{A}_{1} \quad$ : Metode bermain sambil belajar

$\mathrm{A}_{2} \quad$ : Metode belajar secara formal

$\mathrm{B}_{1} \quad$ : Kreativitas tinggi

$\mathrm{B}_{2} \quad$ : Kreativitas rendah

$\mathrm{A}_{1} \mathrm{~B}_{1}$ : Kematangan sekolah pada anak yang diberikan metode bermain sambil belajar dengan kemampuan kreativitas tinggi.

$\mathrm{A}_{1} \mathrm{~B}_{2}$ : Kematangan sekolah pada anak yang diberikan metode bermain sambil belajar dengan kemampuan kreativitas rendah.

$\mathrm{A}_{2} \mathrm{~B}_{1}$ : Kematangan sekolah pada anak yang diberikan metode belajar secara formal dengan kemampuan kreativitas tinggi.

$\mathrm{A}_{2} \mathrm{~B}_{2}$ : Kematangan sekolah pada anak yang diberikan metode belajar secara formal dengan kemampuan kreativitas rendah.

Dalam penelitian ini, untuk menguji hipotesis penelitian digunakan tehnik analisis varians (ANAVA) dua jalur (desain faktorial 2 $x$ 2) dengan menggunakan pengujia taraf signifikansi 0,05 ( $5 \%$ ).

Untuk memberikan arah dalam analisis data, maka hipotesis yang diajukan dapat dinyatakan sebagai berikut: $\mathrm{MP}_{\mathrm{F}}$

a. Hipotesis pertama : Ho : $\mu \mathrm{MP}_{\mathrm{B}}=\mu$

Ha $: \mu \mathrm{MP}_{\mathrm{B}}>\mu \mathrm{MP}_{\mathrm{F}}$
b. Hipotesis kedua $\mathrm{Ha}: \mu \mathrm{K}_{\mathrm{T}}>\mu \mathrm{K}_{\mathrm{R}}$ c. Hipotesis ketiga : Ho : MP $><\mathrm{K}=0$

Ha : MP $><\mathrm{K} \neq 0$

Keterangan :

$\mathrm{MP}=$ metode pembelajaran

$\mathrm{K}=$ kreativitas

$\mathrm{MP}_{\mathrm{B}}=$ metode pembelajaran bermain

$\mathrm{MP}_{\mathrm{F}}=$ metode pembelajaran formal

$\mathrm{K}_{\mathrm{T}} \quad=$ kreativitas tinggi

$\mathrm{K}=$ kreativitas rendah

$\mu \quad=$ Rata-rata skor kematangan sekolah

Ketentuan penerimaan atau penolahan hipotesis yang diajukan adalah hipótesis yang peneliti ajukan diterima apabila nilai $\mathrm{F}$ hitung > $\mathrm{F}$ tabel demikian sebaliknya.

Sebelum melakukan uji hipotesis dengan menggunakan ANAVA, terlebih dahulu uji persyaratan data penelitian yaitu uji normalitas data dengan menggunakan teknik liliefors serta melakukan uji homogenitas varians sampel menggunakan teknik Fisher dan Bartlett. Setelah

pengujian hipotesis dilakukan maka dilakukan pengujian uji lanjut dengan menggunakan uji Scheffe.

\section{HASIL DAN PEMBAHASAN \\ Hasil}

Pengujian hipotesis penelitian pertama, kedua dan ketiga dilakukan dengan menggunakan analisis varians faktorial $2 \times 2$. Rangkuman hasil perhitungannya dapat dilihat pada Tabel 2. 
Tabel 2. Rangkuman Anava Faktorial 2 x 2

\begin{tabular}{|c|c|c|c|c|c|}
\hline Sumber Variasi & dk & $\mathbf{J k}$ & Rjk & F-hitung & F-tabel $_{(1,74)}(\alpha=0,05)$ \\
\hline Metode Pembelajaran & 1 & 6481,03 & 6481,03 & 133,87 & \multirow{5}{*}{ 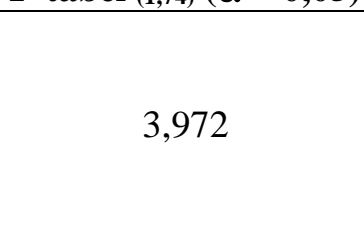 } \\
\hline Kreativitas & 1 & 292,32 & 292,32 & 6,03 & \\
\hline Interaksi & 1 & 343,58 & 343,58 & 7,09 & \\
\hline Galat & 74 & 3582,52 & 48,41 & & \\
\hline Total & 77 & 10699,45 & - & & \\
\hline
\end{tabular}

Pengujian hipotesis pertama yaitu: Kematangan sekolah anak yang diajar dengan metode bermain sambil belajar lebih tinggi dibandingkan dengan anak yang diajar dengan metode pembelajaran secara formal.

Hipotesis statistiknya adalah:

Hipotesis 1: $\quad$ Ho $: \mu \mathrm{MP}_{\mathrm{B}}=\mu \mathrm{MP}_{\mathrm{F}}$

$$
\mathrm{Ha}: \mu \mathrm{MP}_{\mathrm{B}}>\mu \mathrm{MP}_{\mathrm{F}}
$$

Berdasarkan perhitungan Anava faktorial $2 \times 2$ diperoleh F-hitung $=133,87$ sedangkan nilai $\mathrm{F}$ tabel $=3,972$ untuk $\mathrm{dk}(1,74)$ dan taraf nyata $\alpha$ $=0,05$. ternyata nilai F-hitung $=133,87>\mathrm{F}$ tabel $=3,972$ sehingga pengujian hipotesis menolak Ho. Dengan demikian dapat ditarik kesimpulan bahwa kematangan sekolah anak yang diajar dengan metode bermain lebih tinggi dibandingkan dengan yang diajar dengan metode formal teruji kebenarannya. Hal ini juga terlihat dari rata-rata hasil tes kematangan sekolah anak yang diajar dengan metode pembelajaran bermain ( $\bar{X}=58,07$ ) lebih tinggi dari hasil tes kematangan sekolah anak yang diajar dengan metode pembelajaran formal $(\bar{X}$ $=54,20$ ).

Pengujian hipotesis kedua yaitu: Kematangan sekolah pada anak prasekolah yang memiliki kemampuan kreativitas tinggi lebih tinggi dari pada anak prasekolah yang memiliki kemampuan kreativitas rendah..

Hipotesis statistiknya adalah:

Hipotesis 2: $\quad$ Ho : $\mu \mathrm{K}_{\mathrm{T}}=\mu \mathrm{K}_{\mathrm{R}}$

$\mathrm{Ha}: \mu \mathrm{K}_{\mathrm{T}}>\mu \mathrm{K}_{\mathrm{R}}$

Berdasarkan perhitungan Anava faktorial $2 \times 2$ diperoleh $\mathrm{F}$-hitung $=6,03$ sedangkan nilai $\mathrm{F}$ tabel $=3,972$ untuk dk $(1,74)$ dan taraf nyata $\alpha$
$=0,05$. ternyata nilai F-hitung $=6,03>$ F-tabel $=3,972$ sehingga pengujian hipotesis menolak Ho. Dengan demikian dapat ditarik kesimpulan bahwa kematangan sekolah anak dengan tingkat kecenderungan kreativitas tinggi lebih tinggi dari pada anak dengan kecenderungan kreativitas rendah teruji kebenarannya. Hal ini juga terlihat dari rata-rata hasil tes kematangan sekolah anak dengan kreativitas tinggi $(\bar{X}=$ $65,25)$ lebih tinggi dari hasil tes kematangan sekolah anak dengan kreativitas rendah $(\bar{X}=$ 47,02).

Pengujian hipotesis ketiga yaitu: terdapat interaksi antara metode pembelajaran dan kreativitas dalam memberikan pengaruh terhadap kematangan sekolah.

Hipotesis statistiknya adalah:

Hipotesis 3: $\quad$ Ho : $\mathrm{MP}><\mathrm{K}=0$

Ha : MP $><\mathrm{K} \neq 0$

Berdasarkan perhitungan Anava faktorial 2 x 2 diperoleh F-hitung $=7,09$, sedangkan nilai $\mathrm{F}$ tabel $=3,972$ untuk dk $(1,74)$ dan taraf nyata $\alpha$ $=0,05$ ternyata nilai F-hitung $=7,09>$ F-tabel $=$ 3,972 sehingga pengujian hipotesis menolak Ho. Dengan demikian dapat ditarik kesimpulan bahwa terdapat interaksi antara metode pembelajaran dan kreativitas dalam memberikan pengaruh terhadap kematangan sekolah teruji kebenarannya.

Untuk mengetahui interaksi antara metode pembelajaran dan kreativitas terhadap kematangan sekolah anak dilakukan uji lanjut dengan uji Scheffe.. Rangkuman perhitungan uji Scheffe tertera pada Tabel 3.

Tabel 3. Rangkuman Uji Scheffe

\begin{tabular}{|l|c|l|c|}
\hline \multicolumn{2}{|c|}{ Hipotesis Statistik } & $\mathrm{F}_{\text {-hitung }}$ & $\mathrm{F}_{\text {-tabel }(3,74)}(\alpha=0,05)$ \\
\hline $\mathrm{H}_{\mathrm{O}: \mu 11=\mu 12}$ & $\mathrm{Ha}_{: \mu 11>\mu 12}$ & $1,62^{\mathrm{ns}}$ & 2,716 \\
\hline $\mathrm{H}_{\mathrm{O}: \mu 11=\mu 21}$ & $\mathrm{Ha}: \mu 11>\mu 21$ & $4,61^{*}$ & 2,716 \\
\hline $\mathrm{H}_{\mathrm{O}: \mu 11=\mu 22}$ & $\mathrm{Ha}: \mu 11>\mu 22$ & $4,45^{*}$ & 2,716 \\
\hline $\mathrm{H}_{\mathrm{O}: \mu 12=\mu 21}$ & $\mathrm{Ha}_{: \mu 12>\mu 21}$ & $2,93^{*}$ & 2,716 \\
\hline $\mathrm{H}_{\mathrm{O}: \mu 12=\mu 22}$ & $\mathrm{Ha}_{: \mu 12>\mu 22}$ & $2,74^{*}$ & 2,716 \\
\hline $\mathrm{H}_{\mathrm{O}: \mu 21=\mu 22}$ & $\mathrm{Ha}_{: \mu 21>\mu 22}$ & $0,24^{\mathrm{ns}}$ & 2,716 \\
\hline
\end{tabular}


Secara keseluruhan hasil uji Scheffe menunjukkan dari enam kombinasi perbandingan rata-rata hasil tes kematangan sekolah maka berdasarkan Tabel 3 terdapat dua dari enam menunjukkan hasil yang tidak signifikan. Dua yang tidak signifikan tersebut adalah rata-rata tes kematangan sekolah antara kelompok anak yang diajar dengan metode pembelajaran bermain dan kreativitas tinggi dengan kelompok anak yang diajar dengan metode pembelajaran formal dengan kreativitas tinggi. Demikian juga yang tidak signifikan antara kelompok anak yang diajar dengan metode pembelajaran bermain dan kreativitas rendah dengan kelompok anak yang diajar dengan metode pembelajaran formal dan kreativitas rendah.

Namun demikian terdapat interaksi metode pembelajaran dan kreativitas terhadap kematangan sekolah, hal ini terlihat dari metode pembelajaran bermain memberikan hasil

\section{Rata-Rata Hasil Belajar}

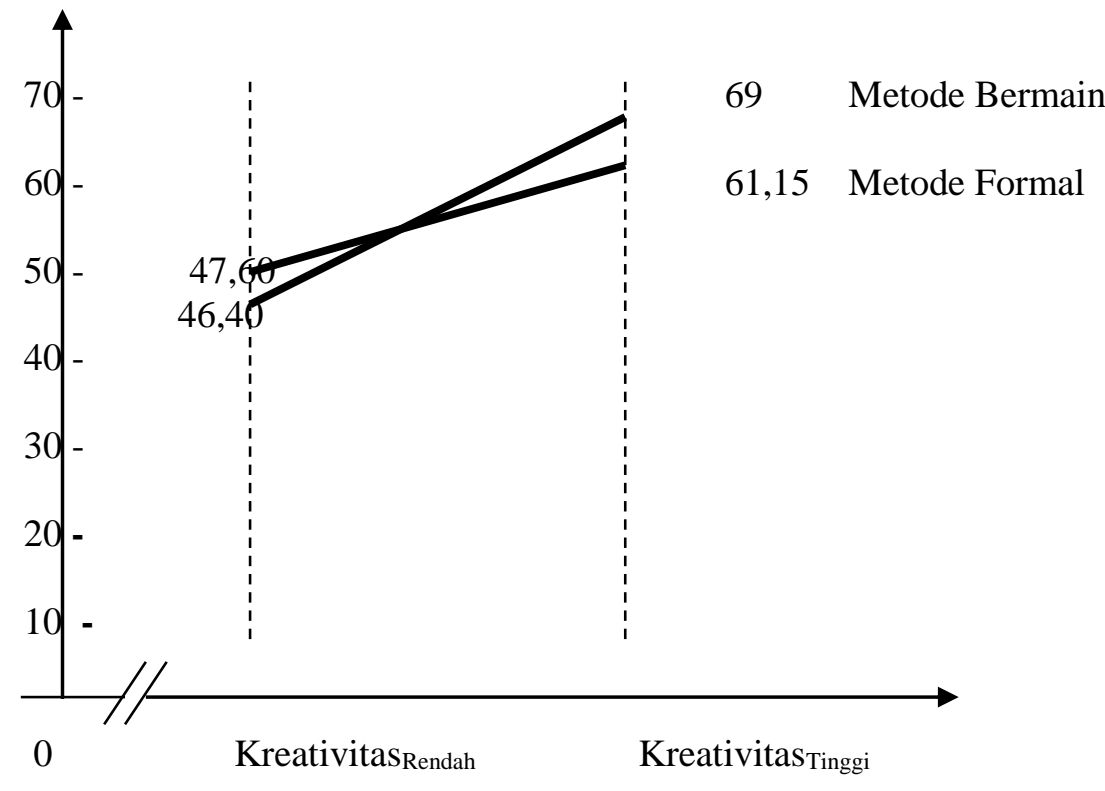

Gambar 1. Interaksi Metode Pembelajaran Dan Kreativitas

\section{Pembahasan}

Secara keseluruhan rata-rata hasil tes kematangan sekolah anak Mandiri Plus Lubuk Pakam yang diajar dengan metode pembelajaran bermain $(\bar{X}=58,07)$ lebih tinggi daripada rata-rata hasil tes kematangan sekolah anak yang diajar dengan metode pembelajaran formal $(\bar{X}=54,20)$. Hal ini menunjukkan bahwa metode pembelajaran bermain terbukti efektif untuk meningkatkan kematangan kematangan sekolah yang lebih tinggi pada anak dengan kreativitas tinggi dari pada anak dengan kreativitas rendah dan metode pembelajaran formal memberikan kematangan sekolah belajar yang lebih tinggi pada anak dengan kreativitas tinggi dari pada anak dengan kreativitas rendah, juga terbukti. Hal ini diketahui dari rata-rata skor hasil tes kematangan sekolah anak yang diajar dengan metode pembelajaran bermain pada anak dengan kreativitas tinggi ( $\bar{X}=69$ ) lebih tinggi dari anak dengan kreativitas rendah $(\bar{X}=$ $46,40)$ dan rata-rata hasil tes kematangan sekolah anak yang diajar dengan metode pembelajaran formal pada anak dengan kreativitas tinggi $(\bar{X}=61,15)$ lebih tinggi dari anak dengan kreativitas rendah ( $\bar{X}=47,60$ ).

Interaksi metode pembelajaran dan kreativitas ditunjukkan Gambar 1.

Metode Bermain

61,15 Metode Formal sekolah anak secara keseluruhan baik untuk kelompok anak dengan kreativitas tinggi maupun anak dengan kreativitas rendah. Hasil temuan ini menunjukkan bahwa untuk mengajarkan materi di Taman Kanak-Kanak lebih baik menggunakan metode pembelajaran belajar sambil bermain daripada dengan metode pembelajaran formal. Hal ini didukung Mulyadi (1997) bahwa bagi anak usia dini, bermain merupakan kebutuhan hakiki bagi seorang anak, oleh sebab itu segala aktivitas 
anak tidak dapat dilepaskan dari unsur bermain. Melalui bermain, anak belajar, dengan bermain anak mengembangkan segenap potensinya dan dengan bermain kreativitas anak dapat terlatih. Hal senada diungkapkan juga oleh Tedjasaputra (2003) menyatakan bahwa melalui bermain anak merasakan berbagai pengalaman emosi, senang, sedih, bergairah, kecewa, bangga, marah dan sebagainya melalui bermain anak pula dapat memahami kaitan antara dirinya dan lingkungan sosialnya.

Temuan penelitian ini mendukung penelitian Hartono (1992) yang melakukan observasi terhadap dua taman kanak-kanak yang memiliki orientasi pembelajaran yang berbeda yaitu taman kanak-kanak yang memegang prinsip perkembangan secara utuh yang sangat mementingkan aktivitas bermain (bermain sambil belajar) dan taman kanak-kanak yang mendidik secara disiplin mengajarkan membaca, menulis dan berhitung dalam porsi yang cukup banyak (belajar secara formal). Hasil penelitiannya menunjukkan bahwa anak tamatan taman kanak-kanak yang "belajar secara formal " menjadi juara kelas pada catur wulan I dan II. Namun pada catur wulan berikutnya dan pada kelas selanjutnya anak tamatan taman kanak-kanak "bermain sambil belajar" yang menduduki peringkat, dan sekali mereka menjadi juara kelas ternyata tak tergeserkan lagi, hingga akhirnya yang menjadi juara ujian nasional di sekolah dasar tersebut adalah anak tamatan taman kanak-kanak bermain sambil belajar. Menurutnya hal ini disebabkan aktivitas bermain sambil belajar mampu memberikan fondasi yang kuat dari berbagai aspek, yaitu kognitif, afektif, dan psikomotorik, sehingga anak memiliki kepribadian yang tangguh, percaya diri dan tidak mudah menyerah.

Jika diperhatikan lebih lanjut bahwa dalam metode pembelajaran bermain rata-rata hasil tes kematangan sekolah anak dengan kreativitas tinggi $(\bar{X}=69)$ lebih tinggi daripada hasil tes kematangan sekolah anak dengan kreativitas rendah $(\bar{X}=46,40)$. Sedangkan pada metode pembelajaran formal, rata-rata hasil tes kematangan sekolah anak dengan kreativitas tinggi $(\bar{X}=61,15)$ lebih tinggi daripada hasil tes kematangan sekolah anak dengan kreativitas rendah $(\bar{X}=47,60)$. Hal ini menunjukkan bahwa metode pembelajaran dan kreativitas signifikan untuk membedakan kematangan sekolah anak, di mana kematangan sekolahh anak dengan kreativitas tinggi baik yang diajar dengan metode pembelajaran bermain, sedangkan bagi anak dengan kreativitas rendah lebih baik diajar dengan metode pembelajaran formal.

Temuan penelitian ini mendukung hasil penelitian yang dilakukan Sugito (2004) menemukan penerapan metode pembelajaran dan kreativitas mempengaruhi hasil belajar siswa. Dalam belajar menggambar, anak yang memiliki kreativitas tinggi dan rendah yang diberikan metode mencontoh menunjukkan peningkatan yang signifikan terhadap hasil belajarnya, namun pada saat belajar menggambar dengan menggunakan metode ekspresi bebas hanya anak yang memiliki kreativitas tinggi yang menunjukkan hasil belajar yang baik, sedangkan pada anak dengan kemampuan kreativitas rendah tidak menunjukkan adanya peningkatan hasil belajar secara signifikan.

Hasil penelitian ternyata menunjukkan semua hipotesis penelitian yaitu: (1) kematangan sekolah pada anak prasekolah yang di ajar dengan metode bermain sambil belajar lebih tinggi dibandingkan dengan anak prasekolah yang di ajar dengan metode pembelajaran secara formal, (2) kematangan sekolah pada anak prasekolah yang memiliki kemampuan kreativitas tinggi lebih tinggi dari pada anak prasekolah yang memiliki kemampuan kreativitas rendah dan (3) terdapat interaksi antara metode pembelajaran dan kreativitas dalam memberikan pengaruh terhadap kematangan sekolah, maka ketiga hipotesis penelitian diterima.

Hipotesis pertama yang menyatakan kematangan sekolah pada anak prasekolah yang di ajar dengan metode bermain sambil belajar lebih tinggi dibandingkan dengan anak prasekolah yang di ajar dengan metode pembelajaran secara formal. Hal ini dapat dimaklumi karena melalui metode pembelajaran belajar sambil bermain dapat mendorong anak untuk aktif belajar karena anak dapat mempelajari suatu ketrampilan melalui aktivitas yang dilakukan ketika bermain. Oleh karena itu, peran tenaga pengajar dalam pembelajaran bermain sebagai fasilitator yang mengarahkan anak untuk menemukan dan mengkonstruk sendiri pengetahuannya dan menfasiltasi kebutuhan belajarnya.

Pengujian hipotesis kedua menunjukkan bahwa hasil tes kematangan sekolah anak yang memiliki kreativitas tinggi 
lebih tinggi dari pada hasil tes kematangan sekolah anak yang memiliki kreativitas rendah. Hasil ini membuktikan bahwa kreativitas signifikan untuk membedakan tingkat kematangan sekolah anak. Kreativitas dalam penelitian ini dikategorikan atas dua kategori yaitu tinggi dan rendah. Dari hasil analisis data secara keseluruhan diperoleh rata-rata hasil tes kematangan sekolah anak dengan kreativitas tinggi lebih tinggi daripada hasil tes kematangan sekolah anak dengan kreativitas rendah. Hal ini menunjukkan bahwa anak yang memiliki kreativitas tinggi secara rata-rata mempunyai hasil tes kematangan sekolah lebih baik dibandingkan dengan anak dengan kreativitas rendah. Dengan demikian anak dengan kreativitas tinggi lebih memahami dan menguasai materi ajar atau ketrampilan yang diajarkan dibandingkan anak yang memiliki kreativitas rendah.

Dari pengujian hipotesis ketiga terdapat interaksi antara metode pembelajaran dan kreativitas dalam mempengaruhi kematangan sekolah anak. Apabila dilihat rata-rata hasil tes kematangan sekolah pada kelompok anak dengan kreativitas tinggi yang diajar dengan metode pembelajaran bermain lebih tinggi dibandingkan dengan rata-rata hasil tes kematangan sekolah anak yang diajar dengan metode pembelajaran formal. Kemudian ratarata hasil tes kematangan sekolah anak dengan kreativitas rendah yang diajar dengan metode pembelajaran bermain lebih rendah dibandingkan dengan rata-rata hasil tes kematangan sekolah anak dengan kreativitas rendah yang diajar dengan metode pembelajaran formal. Hal ini berarti bahwa bagi kelompok anak dengan kreativitas rendah lebih baik menggunakan metode pembelajaran formal dibandingkan dengan menggunakan metode pembelajaran bermain.. Dengan demikian dapat ditarik kesimpulan bahwa metode pembelajaran dan kreativitas cukup signifikan mempengaruhi kematangan sekolah anak.

Selanjutnya hasil pengujian uji lanjut dengan uji Scheffe dari 6 kombinasi yang terdapat dalam pengujian maka terdapat empat kombinasi yang menunjukkan hasil yang signifikan dan dua kombinasi yang menunjukkan hasil yang tidak signifikan dengan rincian: (1) rata-rata tes kematangan sekolah anak yang diajar dengan metode bermain dengan kreativitas tinggi $(\bar{X}=69)$ lebih tinggi dibandingkan rata-rata tes kematangan anak yang diajar dengan metode formal dengan kreativitas tinggi ( $\bar{X}=61,15)$, (2) rata-rata tes kematangan anak yang diajar dengan metode bermain dan kreativitas tinggi $(\bar{X}=69$ ) lebih tinggi dibandingkan dengan rata-rata tes kematangan anak yang diajar dengan metode bermain kreativitas rendah $(\bar{X}$ $=46,40$ ), (3) rata-rata tes kematangan anak yang diajar dengan metode bermain dengan kreativitas tinggi $(\bar{X}=69)$ lebih tinggi dari rata-rata tes kematangan anak yang diajar dengan metode formal dengan kreativitas rendah $(\bar{X}=47,60)$, (4) rata-rata tes kematangan anak siswa yang diajar dengan metode formal dengan kreativitas tinggi $(\bar{X}=$ $61,15)$ lebih tinggi dari rata-rata tes kematangan anak yang diajar dengan metode bermain dengan kreativitas rendah $(\bar{X}=46,40)$, (5) rata-rata tes kematangan anak yang diajar dengan metode formal dengan kreativitas tinggi ( $\bar{X}=61,15$ ) lebih tinggi dari rata-rata tes kematangan anak yang diajar dengan metode formal dan kreativitas rendah $(\bar{X}=47,60)$, dan (6) rata-rata tes kematangan anak yang diajar dengan metode bermain dan kreativitas rendah $(\bar{X}=46,40)$ lebih rendah dari rata-rata tes kematangan anak yang diajar dengan metode formal dan kreativitas rendah ( $\bar{X}=$ $47,60)$.

\section{PENUTUP}

Dari hasil analisis penelitian yang dapat ditarik dari hasil pengujian hipotesis adalah sebagai berikut:

Pertama, terdapat perbedaan rata-rata hasil tes kematangan sekolah anak yang diajar dengan metode pembelajaran bermain secara keseluruhan baik pada kelompok anak dengan kreativitas tinggi maupun kreativitas rendah lebih tinggi dibandingkan dengan rata-rata hasil tes kematangan sekolah anak yang diajar dengan metode pembelajaran formal. Dengan demikian metode pembelajaran bermain lebih efektif diterapkan dalam pembelajaran di Taman Kanak-Kanak guna meningkatkan kematangan sekolah anak.

Kedua, rata-rata hasil tes kematangan sekolah anak dengan kreativitas tinggi secara keseluruhan baik yang diajar dengan strategi pembelajaran bermain maupun metode pembelajaran formal lebih tinggi dibandingkan dengan rata-rata hasil tes kematangan sekolah anak dengan kreativitas rendah. 
Ketiga, hasil perhitungan analisis varians menunjukkan bahwa terdapat interaksi antara metode pembelajaran dengan kreativitas, dimana rata-rata hasil tes kematangan anak dengan kreativitas tinggi lebih baik diajar dengan menggunakan metode pembelajaran bermain dibandingkan dengan menggunakan metode pembelajaran formal, sedangkan bagi anak dengan kreativitas rendah lebih baik diajar dengan menggunakan metode pembelajaran formal dibandingkan dengan metode pembelajaran bermain.

\section{DAFTAR PUSTAKA}

DePorter, B. dan Hernacki, M. 2003. Quantum Learning, Unleashing The Genius In You. Quantum Learning Membiasakan Belajar Nyaman dan Menyenangkan. Alih Bahasa: Alwiyah Abdurrahman. Bandung: Kaifa

Hartono, B. 2002. Anak Anda di TK. Jakarta: Gunung Mulia

Hawadi, R.A. 2004. Psikologi Perkembangan Anak, Jakarta: Grasindo

Hergenhahn, B.R dan Olson, M.H. 2008. Theories of Learning (Teori Belajar). Jakarta: Kencana Prenada Media Group

Kementerian Pendidikan Nasional, 2004. Kurikulum Taman Kanak-Kanak Tahun 2004, Jakarta: Direktorat Jenderal Pendidikan Dasar dan Menengah

Moeslichatoen, R. 2004. Metode Pengajaran di Taman Kanak-Kanak. Jakarta: Rineka Cipta

Munandar, S.C U. 2002. Kreativitas Dan Keberbakatan Strategi Mewujudkan Potensi Kreatif dan Bakat. Jakarta" Gramedia

Musfiroh, T. 2008, Cerdas Melalui Bermain. Jakarta: Grasindo

Mutiah, D. 2010. Psikologi Bermain Anak Usia Dini. Jakarta: Kencana Prenada Media Group
Patmonodewo, S. 2003. Pendidikan Anak Prasekolah. Jakarta: Rineka Cipta

Pratisti, W.D. 2008. Psikologi Anak Usia Dini. Jakarta: Indeks

Rachmawati, Y. Dan Kurniati, E. 2010. Strategi Pengembangfan Kreativitas Anak Pada Anak Usia Taman Kanak-Kanak. Jakarta: Kencana Prenada Media Group

Rahman, S.H. 2005. Konsep Dasar Pendidikan Anak Usia Dini. Yogyakarta: Grafindo Litera Media

Riyanto, T. dan Handoko, M. 2004. Pendidikan Anak Usia Dini. Jakarta; Grasindo

Rose, C. 2003. Master It Faster. Kuasai Lebih Cepat. Alih Bahasa: Femmy Syahrani, Bandung: Kaifa

Seels, B.C. and Richey, R.C. 1994. Instructional Technology, The Defenition and Domains of The Field, Washington. Terjemahan. Yusufhadi Miarso dkk

Santrock, J.W. 2007. Educational Psychology $2^{\text {nd }}$ Edition. Alih Bahasa: Tri Wibowo B.S. Psikologi Pendidikan. Jakarta: Kencana Predana Media Group 2002. Belajar dan Pembelajaran Dalam Taraf Usia Dini Jakarta: Prenhallindo

Sternberg, R.J. 2008. Cognitive Psychology. Fourth Edition. Psikologi Kognitif. Alih Bahasa: Yudi Santoso, Yogyakarta: Pustaka Pelajar

Sudjana, S. 2001. Metode dan teknik Pembelajaran Partisipatif. Bandung: falah Production

Suparman, A. 2001. Desain Instrusional, Jakarta: Universitas Terbuka

Tedjasaputra, M.S. 2003. Bermain, Mainan dan Permainan. Jakarta: Grasindo

Woolfolk. .A.E. 2009. Educational Psychology Active Learning Edition. Bagian Pertama dan Bagian Kedua. Alih Bahasa: Helly Prajitno Soetjipto dan Sri Mulyanti Soetjipto. Yogyakarta: Pustaka Pelajar 